\title{
Ways to Immune Your Finances from the Cost of Heart Disease and Cancer Treatment
}

\author{
S. Yuvavarthini, Y. Franklin Gnanaiah
}

\begin{abstract}
Threateningdiseases such as, cancer and heart disease are emerging as a major public health concern in India. This paper uses LANCET report to specify the background of heart disease and cancer in India. It also provides ways to transfer the out-of-pocket expenditure caused due to the diagnosis of such disease. Further it discusses about policies such as critical illness, heart and cancer insurance, heart insurance. This paper specifies different factors to be taken into consideration while purchasing a policy and assists in selecting the best insurance policy. To check the awareness among general public this paper uses a questionnaire, method to collect samples (of 417 members) and the results are interpreted accordingly. Finally, this paper also provides recommendations for Cancer Cover to make it more effective.
\end{abstract}

Keywords: Cancer, heart disease, cancer cover, heart and cancer insurance, critical illness, awareness.

\section{INTRODUCTION}

In the past 25 years India has witnessed an alarming rise in the occurrence of heart disease, stroke, diabetes and cancers, it has been revealed by The Lancet and its associated journals published on September 2018.

First, the Occurrence of cancer and cardiac problems are so common these days. Statistics by, The National Cancer Registry Program highly proves that more than 1300 people die of cancer every day. And, there is a $34 \%$ rise in heart disease deaths in the past 26 years. The mortality due to cancer has also increased by $6 \%$ in the very recent years and expected to reach up to 17 lakhs by the next year (2020). Since the occurrence of cancer is increasing and so its threat. Hence, it's imperative to purchase a comprehensive plan which covers the disease.

Further, the cost of treatment is also expensive these days. Inflation to quality medical treatments is sky-rocketing. A menacing disease such as cancer needs intensive medical care, the monetary drain caused due to it may ruin all your savings. And, not all can afford the treatment expenses especially in second or advance stages of the disease. The therapy and meditation continues even after surgery. Here comes the necessity of comprehensive health plans. In this regard, cancer insurance plan/ heart and cancer insurance plan works as a savior by covering all the expenses incurred during the course of the disease. And saves you from going bankrupt during a crisis, also acts as an monetary support . Increasing cases of cancer and heart disease, grouped with sky-high medical costs, compels us to have such insurance before it is too late.

Revised Manuscript Received on 14 September, 2019.

S. Yuvavarthini, II M.Sc., Actuarial Science, Bishop Heber College, Trichy- 620 018, Tamilnadu, India.(E-mail: yuvavarthininadar@gmail.com)

Y. Franklin Gnanaiah, Assistant Professor, PG Department of Actuarial Science, Bishop Heber College, Trichy - 620 018, Tamilnadu, India.(E-mail: 25.franka@gmail.com)

\section{METHODOLOGY \&FINANCIAL BURDEN:}

Cancer

In 201755 million were thrown into poverty due to the Out-of-P0cket (OOP) health expenditure, and of these, 38 million $(69 \%)$ were impoverished by the expenditure for medicine, says the new study. These were the calculations by the Public Health Foundation of India (PHFI), an advocacy, which was released on June 6, 2018, and it is based on the official Indian standard for poverty line-a monthly expenditure of Rs 816 in rural areas and Rs 1,000 in urban areas-according to a 2013 report of the erstwhile Planning Commission. The PHFI study used secondary data from National Sample Survey reports and other sources for these estimates.

According to the figures stated in the study (2011-2012) over $80 \%$ of Indians incur OOP-direct payments individuals make to healthcare provides-on healthcare, according to 2011-12 figures cited in the study. It was just around 60\% for the year 1993-1994. In 2011-2012 medicines alone contributed to more than $67 \%$ off OOP health care expenditure.

It is being found that the health care expenditure in India is being dominated by the treatment of cancers, cardiovascular diseases in terms of both outpatient and inpatient care.

The share of diseases such as cardiovascular problems, diabetes, cancer, mental illness, injuries (popularly known as non-communicable disease) in OOP health expenditure increased to $47.3 \%$ in 2004 which war 31.6\% in the year1995-1996.

Also an study estimated that the highest monthly OOP expenditure is being incurred by households on spending on cancer (Rs 5,121), in the case (Rs.3,045) and cardiovascular inpatient care (Rs 2,808

Studies such as PLOS study of 2013, and the World Bank Study of 2014-too had reported the same.

\section{WAYS TO TRANSFER THE OUT-OF-POCKET EXPENDITURE \& RESULTS}

The out-of-pocket expenditure can be avoided if you're purchasing policies such as:

- $\quad$ Mediclaim

- Critical illness

- Cancer cover/heart and cancer cover 
Why you should consider a cancer cover? (Especially for disease cancer)

- Mediclaim will not cover the entire cost of treatment. Because for a disease like cancer hospitalization is not required many a times but, for almost all health insurance policies hospitalization is a must for claim process.

- A critical illness is a defined benefit heath insurance product which pays you in lump sum on the occurrence of insured event. Unlike the traditional health insurance product which pays you the cost incurred for hospitalization alone, a critical illness addresses the issue by providing a defined benefit for incidental expenses, and also supplements your monthly income during the period of recovery. There are several types of critical illness policies available, the coverage of diseases (critical illness) vary between each policy. Typically critical illness covers illness such as cancer, coronary artery bypass graft surgery $(\mathrm{CABG})$, kidney failure, heart attack, major organ transplant and stroke.

- Critical illness plans are much cheaper than comprehensive/traditional health insurance plan as it covers only specified illness. However in spite of such benefits there are also some limitations.

- Though Critical illness addresses the problem of cancer the biggest drawback is that

It covers cancer only at advanced stages but it may cover your first heart attack and even other illness (if the illness is covered in the policy) at an early stage.the same was also mentioned in ET Wealth report.

- $\quad$ Further, a regular critical illness plan provides you a lump sum/defined benefit and it has no feature of waiving all future premiums. Such benefits are provided by a standalone cancer care product.

\section{Benefits of cancer cover policy are:}

- Multiple stages of cancer are covered.

- Lump sum/ defined benefit is paid out on cancer diagnosis.

- Benefit of Premium waiver is available under certain conditions like early stage cancer diagnosis.

- When there are no claims during the year, the sum assured increases by a pre specified percentage.

- $\quad$ Premium discount is available.

- Insurance cover is not ceased after the first diagnosis.

- Tax benefits under section $80 \mathrm{~d}$ of the Income tax act.

\section{Heart and cancer insurance:}

Heart and cancer insurance is an insurance which provides the benefits of cancer insurance plus it provides similar benefits for heart diseases also in the same manner.

\section{Important point to be noted:}

1. Mediclaim is considered as must for everyone. policy as a rider along with your Mediclaim or as a standalone policy one can purchase cancer cover because critical illness covers almost all-important(which has major incidence) heart treatments.
2. In Case, if one has already purchased critical illness

3. If you have not purchased critical illness earlier, you can go for heart and cancer cover.

Parameters to consider before purchasing cancer/heart \& cancer policy:

Here are some of the key points that should be kept in mind before buying a cancer/heart and cancer insurance plan.

i. Always purchase a policy with high sum assured (since its an long term policy)

ii. The Coverage must be for Longer Duration

iii. Ensure that your plan covers cancer of all stages

iv. The Plan Should Provide Premium Waiver and Income Benefit

v. Thoroughly read the Terms and Conditions of Survival and Waiting Period of the Policy

vi. Check Family Health History and weigh risk Factor

vii. Double Policy Does Not Mean Double Coverage

viii. Income Benefit

ix. Tax Benefits

Analysis of awareness about cancer cover and heart and cancer insurance:

To measure the awareness about cancer cover and heart and cancer insurance among general public a questionnaire was given to a sample of say 417 members and following results were obtained using SPSS:

Knowledge about cancer cover:

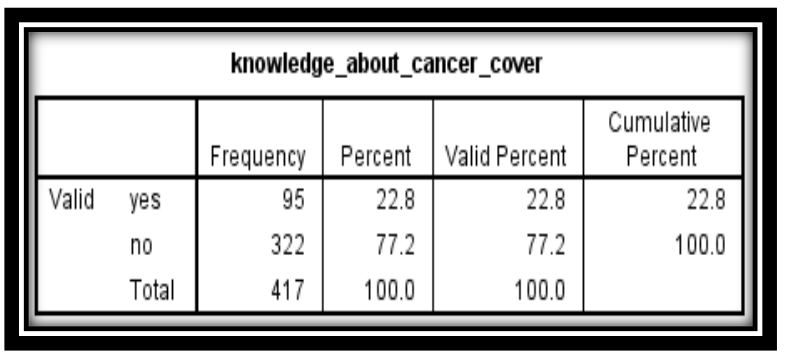

Knowledge about heart and cancer insurance:

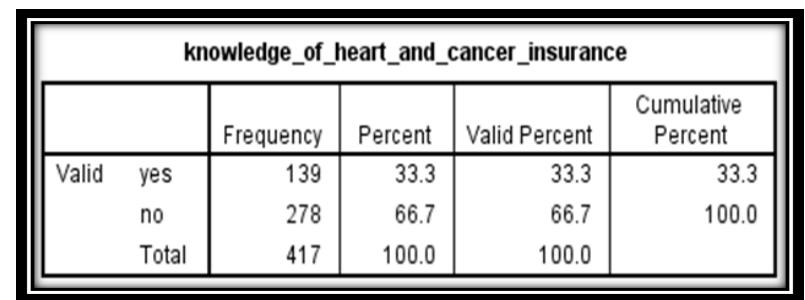

$\%$ of people who have purchased cancer insurance:

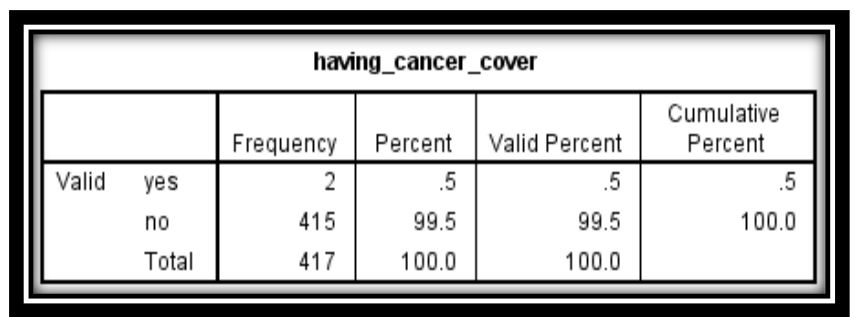

Published By: 
International Journal of Innovative Technology and Exploring Engineering (IJITEE) ISSN: 2278-3075, Volume-8 Issue-12S2, October 2019

$\%$ of people who have purchased heart and cancer insurance:

\begin{tabular}{|c|c|c|c|c|c|}
\hline \multicolumn{6}{|c|}{ purchased_heart_and_cancer_insurance } \\
\hline & & Frequency & Percent & Valid Percent & $\begin{array}{c}\text { Cumulative } \\
\text { Percent }\end{array}$ \\
\hline \multirow[t]{3}{*}{ Valid } & yes & 15 & 3.6 & 3.6 & 3.6 \\
\hline & no & 402 & 96.4 & 96.4 & 100.0 \\
\hline & Total & 417 & 100.0 & 100.0 & \\
\hline
\end{tabular}

Family history and awareness about cancer cover:

\begin{tabular}{|c|c|c|c|}
\hline \multicolumn{4}{|c|}{$\begin{array}{l}\text { family_history_of_cancer “knowledge_about_cancer_cover Crosstabulation } \\
\text { Count }\end{array}$} \\
\hline & \multicolumn{2}{|c|}{$\begin{array}{c}\text { knowledge_about_cancer_cove } \\
\mathrm{r}\end{array}$} & \multirow[b]{2}{*}{ Total } \\
\hline & yes & no & \\
\hline \multirow{3}{*}{$\begin{array}{ll}\text { family_history_of_cancer } & \text { yes } \\
& \text { no } \\
\text { Total } & \end{array}$} & 34 & 56 & 90 \\
\hline & 61 & 266 & 327 \\
\hline & 95 & 322 & 417 \\
\hline
\end{tabular}

Family history and awareness about heart and cancer cover:
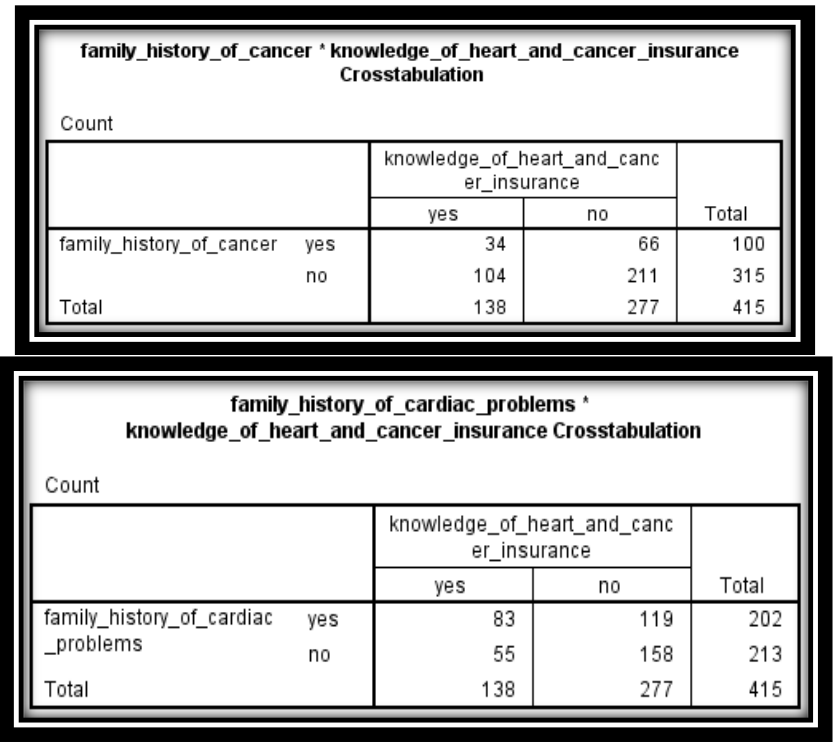

Occupation and knowledge about cancer insurance:

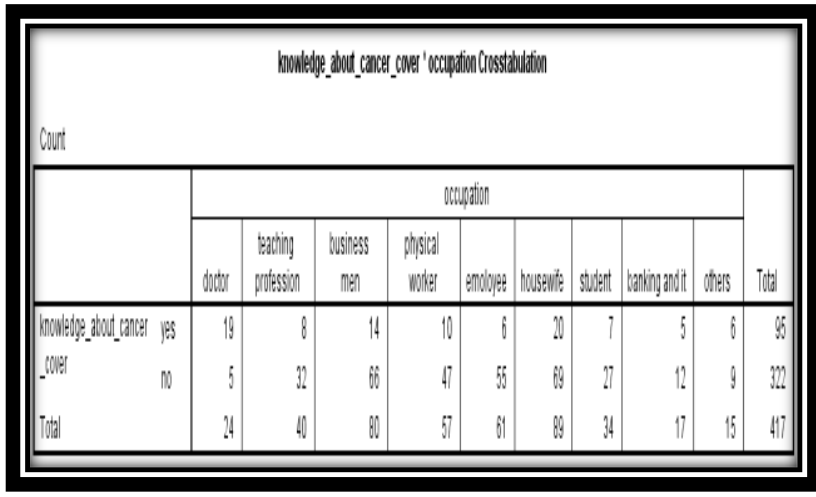

Occupation and knowledge about heart and cancer cover:

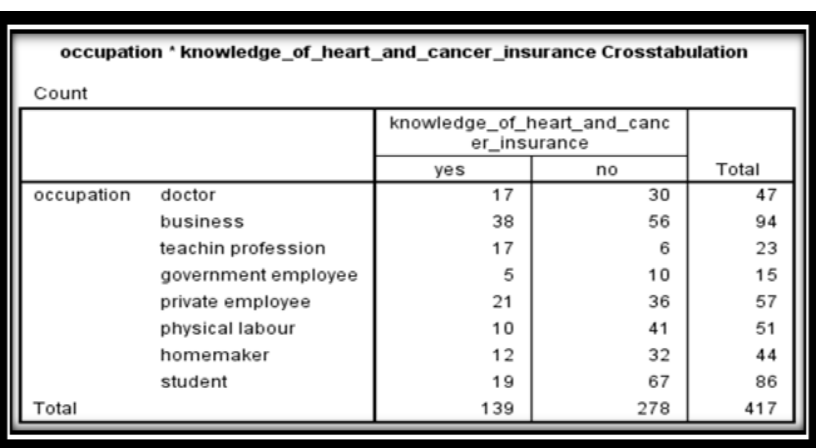

Annova

Cancer cover

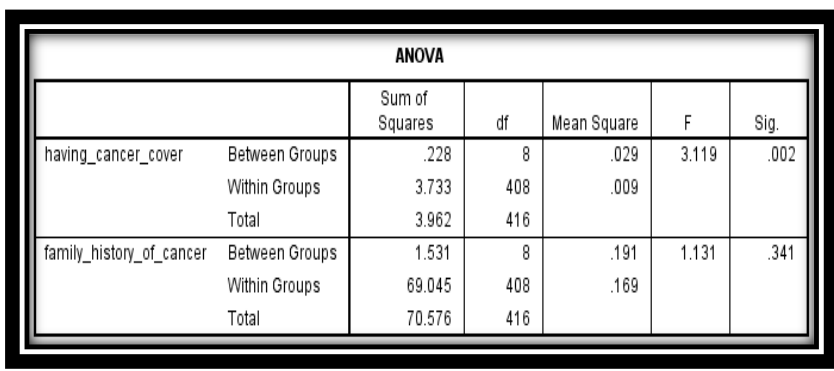

Heart and cancer insurance

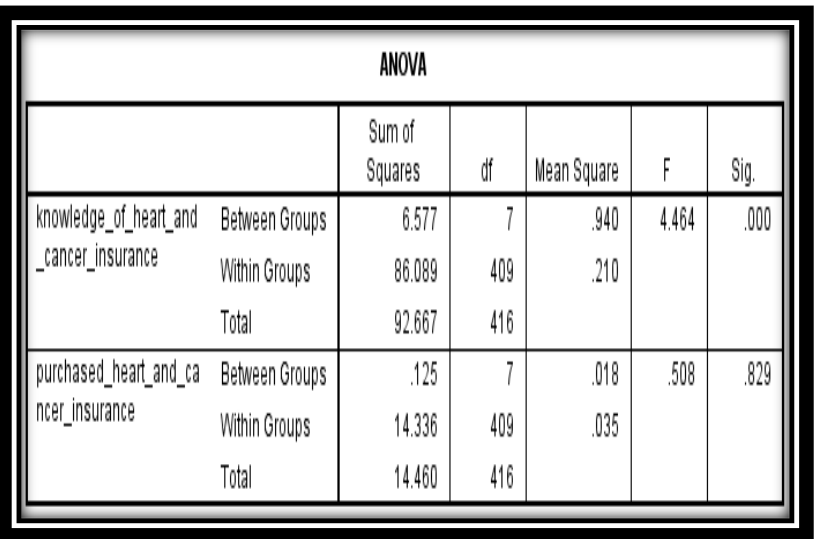

Chi-square test

Cancer cover

\begin{tabular}{||l|r|r|r||}
\hline \multicolumn{4}{|c|}{ Chi-Square Tests } \\
\hline & \multicolumn{1}{|c|}{ Value } & df & $\begin{array}{c}\text { Asymp. Sig. } \\
\text { (2-sided) }\end{array}$ \\
\hline Pearson Chi-Square & $29.205^{\mathrm{a}}$ & 8 & .000 \\
Likelihood Ratio & 25.800 & 8 & .001 \\
Linear-by-Linear & .310 & 1 & .577 \\
Association & & & \\
N of Valid Cases & 417 & & \\
\hline & a. 2 cells (11.1\%) have expected count less than 5. The \\
minimum expected count is 3.24. \\
\hline
\end{tabular}

Published By:

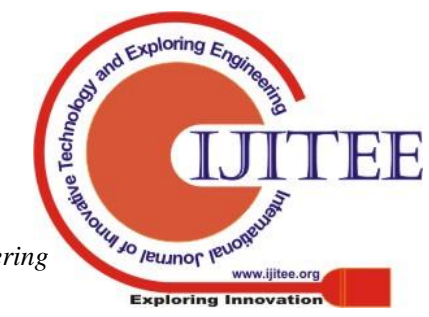




\section{Heart and cancer cover}

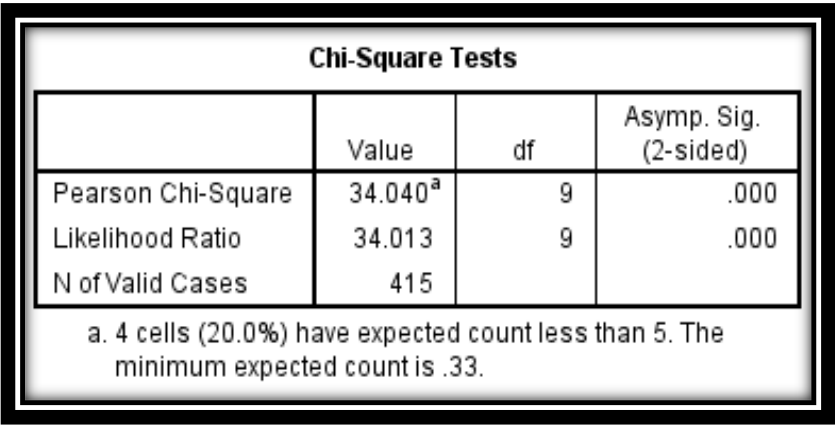

\section{INFERENCES}

- Awareness of cancer cover and heart \& cancer insurance is very low among general public and so only few people have purchased it.

- As per ANNOVA analysis, there is a statistically significant difference in knowing about cancer insurance policy between groups (occupation), and there is no statistically significant difference in cancer cover policy holders between groups (occupation) for both covers.

- $\quad$ As per Chi-square test, occupation and knowledge about cancer cover is dependent.

\section{RECOMMENDATIONS}

\section{Cancer cover}

Cancer cover should include the cost of:

\section{Brest cancer screening:}

- CBE for women between ages 25-40 (recommended every 1 to $3 \mathrm{yrs}$ )

- Annual CBE and screening mammography for women aged $>40$

- Mammography costs nearly 1250-1500

Lip And Oral Cavity Screening

- $\quad$ clinical examination done by dentist and doctors

\section{Cervical Cancer Screening}

- $\quad$ Pap test (alone) for women between ages 21 to 29 (every 3 yrs).

- $\quad$ Pap test and HPV (co -testing)for women > 30 (every 5 years preferred)

- $\quad$ Pap test alone every 3 yrs (for women > 30)

- $\quad$ Pap test costs - RS.1000

HPV costs around -2000

Since these three cancers have major occurrences in India

\section{Heart and cancer cover:}

Heart and cancer cover should consider the recommendations for cancer cover and provide the cost of full body health checkup (annually).

\section{CONCLUSION}

India has an alarming statistics of cancer and heart disease and heart disease. So, this is the right time to think are your finances immune to cancer. And to fight the battle against cancer and heart disease it's better to purchase such policies.

\section{REFERENCES}

1. https://www.indiatoday.in/education-today/gk-currentaff airs/story/cancer-rate-indiastats-cure-treatment1386739-201 8-11-12

2. https://economictimes.indiatimes.com/tdmc/yourmoney/ why-you-should-consider-acancer-insurancepolicy/tomorro wmakersshow/48359687.cms

3. http://www.who.int/cancer/detection/variouscancer/en / https://www.allaboutcancer.fi/facts-aboutcancer/what-iscancer/ https:/

4. https://timesofindia.indiatimes.com/india/500increase-in-ca ncer-incidence-inIndia-by-2025sayexperts/articleshow/473

27699.cms/www.ncbi.nlm.nih.gov/pmc/articles/PMC5 8265 35/

5. https://www.researchgate.net/publication/305404936_ A_ Review_on_Statistics_of_Canc er_in_India https://www.downtoearth.org.in/news/health/9-6millionpeople-will-die-of-cancer-thisyear-61646

6. https://www.indiainfoline.com/article/news-personalfina nce/5-things-to-focus-beforebuying-a-can

7. http://www.searo.who.int/india/topics/cancer/Cancer_ fact_sheet.pdfcerinsuran ce-plan117063000275 1.html

8. https://www.medicinenet.com/cancer_detection/article .ht m\#cancer_screening_test_fact $\mathrm{s}$

9. https://timesofindia.indiatimes.com/life-style/healthfitnes s/health-news/Shocking-factsabout-cancer-inIndia/articlesh ow/50851545.cms

10. http://pib.nic.in/newsite/PrintRelease.aspx?relid=1772 00 https://www.webmd.com/cancer/features/cancerscreenin g-risks-and-benefits\#1

\section{AUTHORS PROFILE:}

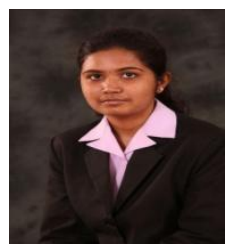

YUVAVARTHINI. S II.M.sc Actuaria science, Bishop Heber College,Trichy (Tamil Nadu), India.. Published a book in the title "Al You Need To Know About Cancer: Don't Let Cancer Ruin All Your Savings" Lambert Publications. Presented papers in national and international conferences. Also published a paper in the title "Economic Burden of Cancer in India: Mediclaim vs Cance cover" in International Journal of Management And IT

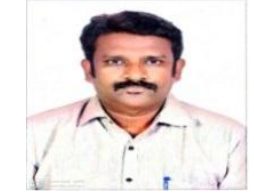

FRANKLIN GNANAIAH .Y M.S (Statistics and Informatics), M. Phil (Statistics) 12+ years of Statistics, Education/Teaching, Data Analyst/DataConsulting Experience.Currently working as an Assistant Professor in the department of Actuarial Science, Bishop Heber College , Trichy . Proficient with SPSS, Ms. Excel, Wincross, programming in R. Presented papers in national and international conferences. Published three papers in international journals.Has also guided many Postgraduate students in their research work. Areas of specialisation are sampling theory and stochastic process. 